\section{Association between the employment status and the presence of depressive symptoms in men and women in Mexico}

\author{
Asociación entre el estatus de empleo y la \\ presencia de síntomas depresivos en \\ hombres y mujeres en México
}

\section{Associação entre situação laboral e presença de sintomas depressivos em homens e mulheres mexicanos}

Julián Alfredo Fernández-Niño 1 Laura Juliana Bonilla-Tinoco 2 Claudia Iveth Astudillo-García 3 Edgar Fabián Manrique-Hernández 2 Vanesa Giraldo-Gartner 4

doi: 10.1590/0102-311X00219617

\begin{abstract}
This study aims to estimate the relationship between employment status and depressive symptoms among Mexican adults, as well as to explore its differential effect by gender. Cross-sectional study of 36,516 adults between 20 and 59 years of age taken from the 2012 Mexican National Health and Nutrition Survey. Depressive symptoms were evaluated using the Center for Epidemiologic Studies Depression Scale (CES-D), and the employment status was determined a week before the survey. Logistic regression models were stratified by gender and education level and adjusted by sociodemographic and health-related conditions to estimate the association between depressive symptoms and employment status. The prevalence of clinically depressive symptoms was $7.59 \%$ for men and $18.62 \%$ for women. In the case of men, those who were unemployed were more likely to present depressive symptoms $(O R=1.66$; 95\%CI: 1.08-2.55) than those who were working. For women, employment status is not associated with the presence of depressive symptoms, except in students $(\mathrm{OR}=1.57$; 95\%CI: 1.02-2.43) compared with those who were working. In both genders, disability preventing one from working was associated with depressive symptoms. Although being employed has been reported to be associated with lower levels of psychiatric morbidity, the estimated effect is different for men and women. Occupational health policies should consider these conditions.
\end{abstract}

Employment; Unemployment; Gender Identity; Depression; Mental Health

\section{Correspondence}

C. I. Astudillo-García

Servicios de Atención Psiquiátrica.

Marina Nacional 60, Ciudad de México 11410, México.

claudiaiveth.astudillo@gmail.com

1 Departamento de Salud Pública, Universidad del Norte, Barranquilla, Colombia.

2 Facultad de Salud, Universidad Industrial de Santander, Bucaramanga, Colombia.

3 Servicios de Atención Psiquiátrica, Ciudad de México, México.

4 University of Massachusetts, Amherst, U.S.A. 


\section{Introduction}

Depression is one of the primary causes of loss of years due to disability worldwide 1 . The age group 15 to 49 years is the most affected, for which depression represents $10.49 \%$ of the burden of the illness (Institute for Health Metrics and Evaluation. GBD compare, 2015. http://vizhub.healthdata.org/gbdcompare, accessed on 29/Jun/2016). While this burden is primarily associated with clinical depression, depressive symptoms are more prevalent. These illnesses have an important effect on adults because they influence their quality of life, result in disability, affect work performance, affect personal, family and social relationships 2,3, and increase the risk of developing psychiatric disorders 3 .

The primary factors identified as the cause of these disorders in adults are genetic 4 and neurobiological factors 5; significant life events, particularly those associated with pathological grief 6 ; psychological factors 7 ; health conditions, particularly those that cause pain 8 ; some specific diseases as hypertension and diabetes 9 ; and social determinants 10 . Regarding social determinants, the risk factors for adults recently identified include the density of social networks 11 , socioeconomic, education 12, and employment status 13,14,15. In general, the impact of these social determinants will depend on the interactions between the coping abilities of each person and the social and material resources available in their environment to handle socioeconomic stress 16.

Employment would seem to have a potentially protective effect on depression in young and middle-aged adults, mainly because of the economic and social benefits of paid work 13. Nevertheless, for those with unstable employment or poor working conditions, employment can be a risk factor for depression 15 , for example, in the case of perceived lack of freedom to make decisions, intimidation or work stress 14 . Most studies suggest a loss of income could mostly explain the relationship between employment and depression; however, additional factors have recently been identified such as feeling useful and empowered, intellectual activity, and social networks 17,18.

The relationship between employment and depression may be different for men and women since gendered forms of social and economic recognition determine work conditions 19,20. In 2006, 63\% of the Mexican workforce was male and 37\% was female; moreover, women tended to work in lower status occupations and with less favorable work conditions compared with men 20 . In Mexico, the effect of employment on depression in adults and mental health of men and women have not been widely explored. Studies have been reported only in specific populations with small samples, for example, Acosta-Rodríguez et al. 21 compare unemployed people $(\mathrm{n}=250)$ versus university students $(\mathrm{n}=$ 346), reporting higher scores of depression in the unemployed. Another study in medium-low socioeconomic level communities $(n=1,156)$ states that occupation and economic limitations were the main factors associated with depression 22. It has also been reported that the principal psychosocial factors associated with depression in the Mexican population are, for women, being the head of the family, dedicating exclusively to housework or being caregivers, and, for men, being unemployed 23 . However, there have been no explorations of these associations between occupation and depressive symptoms in a sample with national representativeness.

Research on the role of the association between employment and depressive symptoms in Mexico is especially relevant considering the recent economic crisis. The country is facing new challenges in the labor market such as rise in labor inequalities and informal employment, weak recovery of salaries, and persistent need for greater participation of female labor force 24,25 . The gender labor dynamics also requires the integration of a gender perspective into the study of mental health and employment. Furthermore, since young adults are an economically productive population, identifying the magnitude and determinants of the occurrence of depressive symptoms in adults is important to the development of public health, and economic and social policies.

Therefore, the objectives of this analysis are: (1) to estimate the association between the employment status and the presence of depressive symptoms in Mexican adults; (2) to evaluate the differences in this association between men and women and across different educational levels; and (3) to evaluate the association with some benefits of employment, also considering differences by gender. 


\section{Methods}

\section{Sample}

The 2012 Mexican National Health and Nutrition Survey (ENSANUT-2012) is representative of the population at the national and state levels as well as in the urban and rural regions. The study sample was obtained using a multistage sampling design and included complete information of 50,528 households (which corresponds to a response rate of $87 \%$ at the household level) and 96,031 individuals, of whom 37,420 were between 20 and 59 years old. People from this age group and who had complete data in all the variables constituted the sample of this study, which yielded an analytical sample of 36,516 individuals. The methodology and design of the ENSANUT-2012 have been described in previous publication 26 .

\section{Data collection instruments}

For this study, data were extracted from the information collected by the household and individual questionnaires administered to the adults over 20 years of age. Previously trained personnel conducted both questionnaires through face-to-face interviews.

\section{Variables}

Clinically significant depressive symptoms were evaluated using the short seven-item Center for Epidemiologic Studies Depression Scale (CES-D) 27. Each item was represented by a Likert scale with four categories and a score from 0 to 3 (from never to always), for a total score ranging from 0 to 21 . A dichotomous variable of the presence of depressive symptoms was then constructed based on the total score and on a previously defined cutoff point for Mexican adults (score $\geq 9$ ), in which sensitivity according to the $10^{\text {th }}$ revision of the International Classification of Diseases (ICD-10) was 90.2, specificity was $86 \%$ and ROC was $88 \%$. Using the 4 th edition of the Diagnostic and Statistical Manual of Mental Disorders (DSM-IV), the values were 80.4, 89.6, and 85\%, respectively 28.

Employment status: ascertained based on the question asking whether the participant had worked "at least one hour last week". By work, it was meant: wage labor, farm labor, self-employment, or own business. The answer options were "yes" or "no" and, in case of a negative answer, the participant could specify the reason for not working at that moment. This reason could be: unemployment, being retired, being a student, being a homemaker or having a disability that prevented them from working. Based on the answers given by the participants, six classification groups were made: (1) currently working, (2) unemployed, (3) retired, (4) student, (5) homemaker, and (6) disability preventing one from working.

Employment benefits: those who worked were also asked whether they had access to the following employment benefits - (1) health care, (2) bonuses, (3) vacations, (4) profit sharing, and (5) retirement savings.

Employment income: this variable was constructed using two questions: the periodicity of their payment (diary, weekly, biweekly, monthly, annually or does not have income); and the amount of money they were paid (Mexican pesos). The monthly income was calculated for people who were classified as currently working and who received money for their work. Finally, income quintiles were constructed and used for the analysis; the first quintile corresponded to the lowest income quintile.

Socioeconomic status (index of goods): an index was used to estimate the socioeconomic status of the households, which other studies previously validated, including the ENSANUT 29. This variable was constructed based on 20 items related to the ownership of goods (refrigerator, television, telephone, cable television, etc.). To this end, a factor analysis was performed using a tetrachoric matrix. The analysis produced a continuous variable whose highest values were associated with the highest accumulated wealth values (socioeconomic status). The quintiles of this variable were used for this study.

Other covariates: gender, age, educational level, residence area (urban, rural or metropolitan), marital status, indigenous background (defined by self-report of speaking an indigenous language), health insurance status, receiving money from governmental programs, self-reported diabetes, and 
self-reported high blood pressure (the most relevant diseases in this age group in Mexico). All the covariates were categorical; the categories of each one can be reviewed in Table 1.

\section{Statistical analysis}

For the descriptive analysis, categorical variables were summarized using proportions and for the bivariate analysis, chi-square test was used to evaluate associations between each categorical covariate and the response variable (presence of depressive symptoms).

Logistic regression models for the presence of clinically significant depressive symptoms were run using employment status as the primary explanatory variable and adjusted for sociodemographic and health-related covariates. All the predictors were categorized for the model specification and all the analyses were stratified by gender. To evaluate the association of current employment status with the presence of depressive symptoms, odds ratios (ORs) were estimated using the described multiple logistic regressions adjusted for all the listed covariates, but also compared with crude ORs obtained with simple logistic regressions.

For a more detailed exploration of the heterogeneity of the association between employment status and depressive symptoms, a stratified analysis by gender and educational level was conducted, in which the adjusted estimates are presented for each combination of these two variables.

Finally, the association between depressive symptoms, employment benefits, and employment income was estimated only for current workers with logistic regression models also adjusted for the same covariates as in the previous models. All the assumptions in each of the adjusted models were evaluated and their goodness of fit was determined using the Hosmer-Lemeshow test. Associations with a p-value under 0.05 were considered statistically significant, and for the stratified analysis, a 0.10 significance level was used given the scarce sample in some strata. All the analyses considered the sampling methods and the multi-stage survey design, and were carried out with Stata 14 (StataCorp LP, College Station, USA).

\section{Ethical statement}

The sample used for this study was obtained from the ENSANUT-2012 survey, which was approved by the ethics and research committee of the National Institute of Public Health (INSP, Spanish acronym). All the participants agreed to participate in the survey and provided written informed consent. The information in the survey is public and can be requested from the INSP. In terms of confidentiality, the database does not contain personal information related to the participants.

\section{Results}

The analytical sample was composed of 36,516 participants who were 20 to 59 years old from all the states in Mexico and who had complete data for the variables of interest. Among these, 58.52\% were women, with a mean age of 37.94 years (interquartile range: 29-46); the mean age for men was 38.07 years (interquartile range: $29-47$ ).

Regarding the main sociodemographic characteristics, $2.99 \%$ of men had no schooling, $26.43 \%$ had complete or partial elementary education, $49.1 \%$ had complete or partial secondary education, $3.45 \%$ had a technical education and $18.02 \%$ had higher education. Women had less formal education, with 4.25\%, 29.15\%, 44.96\%, 7.22\% and 14.43\%, respectively. Illiteracy, as the inability to "read or write a message", had a prevalence of $4.15 \%$ among men and $5.71 \%$ among women. From those without formal education, $73.15 \%$ of men and $80.76 \%$ of women were illiterate.

With respect to the primary health conditions, $1.31 \%$ (95\%CI: 1.07-1.60) of men had diabetes and 1.96\% (95\%CI: 1.64-2.35) had high blood pressure, while 1.46\% (95\%CI: 1.22-1.73) of women had diabetes and 3.24\% (95\%CI: 2.84-3.70) had high blood pressure.

Regarding the employment status, $86.9 \%$ of men were working at the time of the survey (over the previous seven days), whereas only $39.21 \%$ of women were working. In addition, $5.68 \%$ of men and only $1.16 \%$ of women reported being unemployed (noting that women "homemaker" corresponds to 
Table 1

Sociodemographic characteristics and health status of Mexican adults, by gender and presence of depressive symptoms. 2012 Mexican National Health and Nutrition Survey (ENSANUT-2012) *.

\begin{tabular}{|c|c|c|c|c|c|c|c|}
\hline \multirow[t]{2}{*}{ Variables } & \multirow{2}{*}{$\begin{array}{c}\text { All } \\
(\mathrm{N}=36,516)\end{array}$} & \multicolumn{2}{|c|}{ All $(N=36,516)$} & \multicolumn{2}{|c|}{ Men $(n=15,147)$} & \multicolumn{2}{|c|}{ Women $(n=21,369)$} \\
\hline & & $\begin{array}{c}\text { Without } \\
\text { depression } \\
(n=31,390) \\
\%\end{array}$ & $\begin{array}{c}\text { With } \\
\text { depression } \\
(n=5,126) \\
\%\end{array}$ & $\begin{array}{c}\text { Without } \\
\text { depression } \\
(n=13,974) \\
\%\end{array}$ & $\begin{array}{c}\text { With } \\
\text { depression } \\
\begin{array}{c}(n=1,173) \\
\%\end{array}\end{array}$ & $\begin{array}{c}\text { Without } \\
\text { depression } \\
(n=17,416) \\
\%\end{array}$ & $\begin{array}{c}\text { With } \\
\text { depression } \\
(\mathrm{n}=3,953) \\
\%\end{array}$ \\
\hline \multicolumn{8}{|l|}{ Sociodemographic } \\
\hline \multicolumn{8}{|l|}{ Employment status ** } \\
\hline Working & 61.52 & 63.38 & 49.62 & 87.26 & 82.45 & 39.52 & 37.84 \\
\hline Unemployed & 3.27 & 3.30 & 3.08 & 5.35 & 9.66 & 1.26 & 0.72 \\
\hline Retired & 1.06 & 1.07 & 1.04 & 1.31 & 2.26 & 0.83 & 0.60 \\
\hline Student & 3.57 & 3.76 & 2.30 & 4.27 & 1.37 & 3.26 & 2.64 \\
\hline Homemaker & 29.89 & 27.88 & 42.79 & 0.85 & 1.59 & 54.87 & 57.57 \\
\hline $\begin{array}{l}\text { Disability preventing } \\
\text { one from working }\end{array}$ & 0.68 & 0.60 & 1.17 & 0.96 & 2.65 & 0.25 & 0.64 \\
\hline \multicolumn{8}{|l|}{ Age group (years) $* \star$} \\
\hline $20-29$ & 31.77 & 33.17 & 22.75 & 33.60 & 24.21 & 32.74 & 22.23 \\
\hline $30-39$ & 28.07 & 28.28 & 2.54 & 27.01 & 22.17 & 29.95 & 26.55 \\
\hline $40-49$ & 22.66 & 21.91 & 2.75 & 22.37 & 27.73 & 21.44 & 27.42 \\
\hline $50-59$ & 17.51 & 16.44 & 24.36 & 17.02 & 25.90 & 15.87 & 23.80 \\
\hline \multicolumn{8}{|l|}{ Educational level ** } \\
\hline None & 3.66 & 3.13 & 7.10 & 2.71 & 6.47 & 3.54 & 7.33 \\
\hline Elementary & 27.87 & 2.63 & 37.99 & 25.24 & 40.88 & 27.36 & 36.95 \\
\hline Secondary & 46.90 & 47.78 & 41.25 & 49.45 & 44.92 & 46.11 & 39.93 \\
\hline Technical & 5.46 & 5.44 & 5.60 & 3.58 & 1.93 & 7.29 & 6.91 \\
\hline University & 16.11 & 17.36 & 8.06 & 19.03 & 5.79 & 15.70 & 8.88 \\
\hline \multicolumn{8}{|l|}{ Marital status ** } \\
\hline Single & 21.80 & 22.47 & 17.49 & 24.90 & 20.78 & 20.04 & 16.30 \\
\hline Married & 48.57 & 49.16 & 44.79 & 49.40 & 46.31 & 48.91 & 44.25 \\
\hline Free union & 21.13 & 20.84 & 22.96 & 21.88 & 24.27 & 19.80 & 22.49 \\
\hline Divorced & 1.51 & 1.45 & 1.90 & 0.96 & 1.39 & 1.95 & 2.09 \\
\hline Separated & 4.99 & 4.45 & 8.43 & 2.34 & 6.20 & 6.56 & 9.23 \\
\hline Widow & 2.01 & 1.63 & 4.43 & 0.52 & 1.05 & 2.73 & 5.64 \\
\hline Indigenous & 6.20 & 6.19 & 6.27 & 6.03 & 6.74 & 6.35 & 6.10 \\
\hline Having health insurance & 73.88 & 73.68 & 75.13 & 70.10 & 66.21 & 77.26 & 78.33 \\
\hline $\begin{array}{l}\text { Receiving money from } \\
\text { programs } * * *\end{array}$ & 11.65 & 10.95 & 16.15 & 4.56 & 5.26 & 17.32 & 20.05 \\
\hline \multicolumn{8}{|l|}{ Socioeconomic status } \\
\hline \multicolumn{8}{|l|}{ (quintile) \# } \\
\hline 1 st & 22.80 & 22.23 & 26.43 & 20.86 & 28.89 & 23.60 & 25.55 \\
\hline $2^{\text {nd }}$ & 18.24 & 18.06 & 19.39 & 17.40 & 16.84 & 18.73 & 20.30 \\
\hline $3 r d$ & 18.50 & 18.44 & 18.94 & 17.60 & 20.37 & 19.28 & 18.43 \\
\hline $4^{\text {th }}$ & 20.95 & 21.08 & 20.06 & 22.07 & 19.02 & 20.10 & 20.43 \\
\hline $5^{\text {th }}$ & 19.51 & 20.18 & 15.18 & 22.09 & 14.88 & 18.29 & 15.29 \\
\hline \multicolumn{8}{|l|}{ Residence area \# } \\
\hline Rural & 20.65 & 20.31 & 22.88 & 20.40 & 25.68 & 20.22 & 21.88 \\
\hline Urban & 18.42 & 18.30 & 19.14 & 17.75 & 20.32 & 18.85 & 18.72 \\
\hline Metropolitan & 60.93 & 61.39 & 57.98 & 61.85 & 54.00 & 60.94 & 59.40 \\
\hline \multicolumn{8}{|l|}{ Health-related conditions } \\
\hline Diabetes ** & 1.39 & 1.20 & 2.58 & 1.22 & 2.37 & 1.18 & 2.66 \\
\hline High blood pressure ** & 2.65 & 2.23 & 5.30 & 1.87 & 3.13 & 2.60 & 6.07 \\
\hline
\end{tabular}

* Results are presented by columns;

** Significant in men and women;

*** Significant only in women;

\# Significant only in men. 
a different category). Only $1.38 \%$ of men and $0.79 \%$ of women were retired; $4.05 \%$ of men and $3.14 \%$ of women were students; $1.08 \%$ of men and $0.33 \%$ of women had a disability that prevented them from working. Lastly, and highly relevant, 55.38\% of women reported that they were homemakers, while only $0.91 \%$ of men reported to belong to this category. The prevalence of clinically depressive symptoms was 7.59\% (95\%CI: 6.90-8.35) for men and 18.62\% (95\%CI: 17.68-19.59) for women. This estimates are adjusted by the sample design.

Table 1 shows the characteristics of the sample according to the presence of depressive symptoms and gender. Employment status, age group, educational level, marital status, and self-reported diabetes and high blood pressure show a statistically significant association $(p<0.05)$ with the presence of depressive symptoms for both genders. While socioeconomic status is significant only in men, receiving money from social programs is significantly associated in women. A notable difference in the proportions of men without and with depression who are unemployed (5.35\% vs. 9.66\%, respectively) is shown, but this difference is not so marked in women. For the age group, the proportion of people that does not have depression declines as age increases in both genders. Finally, most of men and women with depressive symptoms is married, has secondary education or less, and belongs to the lowest socioeconomic quintile.

The results from the logistic regression model regarding the presence of depressive symptoms for each gender (Table 2) show that, in the case of men, the likelihood of presenting depressive symptoms was higher for those who were unemployed (OR $=1.66$; 95\%CI: 1.08-2.55) compared with those who were currently working. Additionally, a positive association was found for the classification having a disability preventing them from working $(\mathrm{OR}=2.14$; 95\%CI: 1.14-4.03). The likelihood of presenting depressive symptoms was also found to be higher for those who were separated than for those who were single $(\mathrm{OR}=2.12$; 95\%CI: 1.19-3.78). Regarding educational level, secondary or high school $(\mathrm{OR}=2.79$; 95\%CI: 1.90-4.08), elementary $(\mathrm{OR}=4.38$; 95\%CI: $2.90-6.62)$ and no formal education $(\mathrm{OR}=5.75$; 95\%CI: 3.21-10.30) presented higher odds of depression compared with university education. Finally, belonging to an older age group was also associated, so that the likelihood of depression for the 40-49 age group was $\mathrm{OR}=1.63$ (95\%CI: $1.24-2.15)$ and for the 50-59 age group was $\mathrm{OR}=1.77$ (95\%CI: 1.25-2.51), compared with younger ages.

Regarding women (Table 2), being a student (OR $=1.57$; 95\%CI: $1.02-2.43)$ or having a disability preventing from working $(\mathrm{OR}=1.91$; $95 \% \mathrm{CI}$ : 1.05-3.46) increased the likelihood of having depression compared with women who worked. Statistically significant associations were also found for widows versus single women $(\mathrm{OR}=1.43$; 95\%CI: 1.04-1.97). Conversely, lower odds of depression were observed for being married versus being single ( $\mathrm{OR}=0.80$; 95\%CI: 0.67-0.96). An inverse association was found between the likelihood of having depression and educational level, so that techni$\mathrm{cal}(\mathrm{OR}=1.50 ; 95 \% \mathrm{CI}: 1.08-2.07)$, secondary $(\mathrm{OR}=1.57$; 95\%CI: $1.22-2.03)$, elementary $(\mathrm{OR}=2.12$; 95\%CI: 1.62-2.78) and no formal education (OR = 3.13; 95\%CI: 2.21-4.44) had gradually higher odds of depression compared with university education. In terms of age, the odds of depression increased gradually with increasing age: the ORs were 1.31 for the $30-39$ years group (95\%CI: 1.11-1.54), 1.76 for the 40-49 years group (95\%CI: 1.47-2.10) and 1.86 for the 50-59 years group (95\%CI: 1.52-2.28), compared with younger women. Additionally, significant associations were also found for indigenous ethnicity $(\mathrm{OR}=0.73$; 95\%CI: 0.56-0.94) and for self-report of high blood pressure $(\mathrm{OR}=1.93 ; 95 \%$ CI: $1.47-2.53)$.

As to the stratified analysis, Table 3 presents the adjusted ORs, which show the association between unemployment and depression tends to remain in men, especially in the technical $(\mathrm{OR}=$ 1.56; 95\%CI: 1.13-2.15) and secondary (OR = 1.44; 95\%CI: 0.99-2.10) levels of education, in which it is statistically significant at the 0.05 and 0.10 level, respectively. In men with elementary and no formal education, there was no significant association. Finally, the association between unemployment and depression clearly disappeared in men with university education. In the case of women, the association between depressive symptoms and unemployment was significant at 0.10 level among women with secondary educational level $(\mathrm{OR}=1.51$; 95\%CI: 0.94-2.43); on the other hand, only in those who had no education, a positive association between depression and being retired was found $(\mathrm{OR}=2.25$; 95\%CI: 1.02-4.95). Finally, having a disability preventing one from working was significantly associated with having depressive symptoms in men with technical and secondary education and women with technical education. 
Table 2

Logistic regression models for the presence of clinically significant depressive symptoms in Mexican adults, by gender. 2012 Mexican National Health and Nutrition Survey (ENSANUT-2012).

\begin{tabular}{|c|c|c|c|c|c|c|c|c|}
\hline \multirow[t]{3}{*}{ Variables } & \multicolumn{4}{|c|}{ Men $(n=15,147)$} & \multicolumn{4}{|c|}{ Women $(n=21,369)$} \\
\hline & \multicolumn{2}{|c|}{ Crude* } & \multicolumn{2}{|c|}{ Adjusted ** } & \multicolumn{2}{|c|}{ Crude* } & \multicolumn{2}{|c|}{ Adjusted ** } \\
\hline & OR & $95 \% \mathrm{Cl}$ & OR & $95 \% \mathrm{Cl}$ & OR & $95 \% \mathrm{Cl}$ & OR & $95 \% \mathrm{Cl}$ \\
\hline \multicolumn{9}{|l|}{ Sociodemographic } \\
\hline \multicolumn{9}{|l|}{ Employment status [Ref.: working] } \\
\hline Unemployed & $1.91 * \star \star$ & $1.27-2.87$ & $1.66 * \star \star$ & $1.08-2.55$ & $0.59 * \star \star$ & $0.36-0.97$ & 0.73 & $0.45-1.21$ \\
\hline Retired & $1.84 * \star \star$ & $1.02-3.30$ & 1.963 & $0.98-3.93$ & 0.75 & $0.42-1.32$ & 0.60 & $0.32-1.15$ \\
\hline Student & $0.34 * * *$ & $0.14-0.82$ & 0.90 & $0.34-2.35$ & 0.85 & $0.56-1.28$ & $1.57 * \star *$ & $1.02-2.43$ \\
\hline Homemaker & 1.98 & $0.98-3.99$ & 1.49 & $0.75-2.97$ & 1.10 & $0.97-1.24$ & 1.03 & $0.89-1.20$ \\
\hline Disability preventing one from working & $2.94 * \star \star$ & $1.59-5.43$ & $2.14 * \star *$ & $1.14-4.03$ & $2.60 * \star \star$ & $1.38-4.93$ & $1.91 * \star \star$ & $1.05-3.46$ \\
\hline \multicolumn{9}{|l|}{ Age (years) [Ref.: 20-29] } \\
\hline $30-39$ & 1.14 & $0.86-1.52$ & 1.09 & $0.81-1.47$ & $1.31 * \star *$ & $1.12-1.52$ & $1.31 * * *$ & $1.11-1.54$ \\
\hline $40-49$ & $1.72 * \star \star$ & $1.31-2.26$ & $1.63 * \star *$ & $1.24-2.15$ & $1.88 * * *$ & $1.60-2.21$ & $1.76 * \star \star$ & $1.47-2.10$ \\
\hline $50-59$ & $2.11 * \star \star$ & $1.55-2.88$ & $1.77 * \star \star$ & $1.25-2.51$ & $2.21 * \star \star$ & $1.87-2.61$ & $1.86 * \star *$ & $1.52-2.28$ \\
\hline \multicolumn{9}{|l|}{ Educational level [Ref.: university] } \\
\hline Technical & 1.78 & $0.89-3.57$ & 1.65 & $0.82-3.31$ & $1.68 * * *$ & $1.23-2.29$ & $1.50 * \star \star$ & $1.08-2.07$ \\
\hline Secondary & $2.99 * \star \star$ & $2.13-4.19$ & $2.79 * \star \star$ & $1.90-4.08$ & $1.53 * * *$ & $1.21-1.93$ & $1.57 * \star \star$ & $1.22-2.03$ \\
\hline Elementary & $5.32 * * \star$ & $3.78-7.50$ & $4.38 * * *$ & $2.90-6.62$ & $2.39 * * \star$ & $1.88-3.03$ & $2.12 * * *$ & $1.62-2.78$ \\
\hline None & $7.85 * \star \star$ & 4.77-12.95 & $5.75 * \star *$ & $3.21-10.30$ & $3.66 * * *$ & $2.71-4.94$ & $3.13 * * *$ & $2.21-4.44$ \\
\hline \multicolumn{9}{|l|}{ Marital status [Ref.: single] } \\
\hline Married & 1.12 & $0.85-1.49$ & 0.80 & $0.59-1.08$ & 1.11 & $0.94-1.32$ & $0.80 * \star *$ & $0.67-0.96$ \\
\hline Free union & 1.33 & $0.99-1.78$ & 0.96 & $0.70-1.33$ & $1.40 * * *$ & $1.15-1.69$ & 1.12 & $0.92-1.37$ \\
\hline Divorced & 1.74 & $0.90-3.83$ & 1.52 & $0.74-3.14$ & 1.32 & $0.90-1.92$ & 1.05 & $0.71-1.56$ \\
\hline Separated & $3.18 * \star \star$ & $1.79-5.62$ & $2.12 * \star \star$ & $1.19-3.78$ & $1.73 * \star \star$ & $1.34-2.22$ & $1.26 \#$ & $0.98-1.62$ \\
\hline Widow & $2.39 * \star \star$ & $1.13-5.07$ & 1.25 & $0.57-2.76$ & $2.54 * \star \star$ & $1.86-3.45$ & $1.43 * \star \star$ & 1.04-1.97 \\
\hline Indigenous [Ref.: not indigenous] & 1.13 & $0.83-1.53$ & 0.81 & $0.58-1.13$ & 0.96 & $0.76-1.21$ & $0.73 * * *$ & $0.56-0.94$ \\
\hline Having health insurance [Ref.: not health insurance] & 0.84 & $0.67-1.04$ & 0.90 & $0.72-1.13$ & 1.06 & $0.92-1.23$ & 1.05 & $0.91-1.22$ \\
\hline Receiving money from programs [Ref.: not receives] & 1.16 & $0.79-1.71$ & 0.75 & $0.48-1.17$ & $1.20 * \star *$ & $1.05-1.37$ & 0.96 & $0.83-1.11$ \\
\hline \multicolumn{9}{|l|}{ Socioeconomic status (quintile) [Ref.: 1st] } \\
\hline 2nd & $0.70 * * *$ & $0.52-0.93$ & 0.77 \# & $0.57-1.05$ & 1.00 & $0.85-1.18$ & 1.04 & $0.88-1.23$ \\
\hline 3 rd & 0.84 & $0.63-1.11$ & 1.02 & $0.74-1.40$ & 0.88 & $0.75-1.04$ & 0.95 & $0.80-1.12$ \\
\hline 4 th & $0.62 * \star \star$ & $0.47-0.83$ & 0.85 & $0.61-1.17$ & 0.94 & $0.79-1.12$ & 1.06 & $0.88-1.26$ \\
\hline $5^{\text {th }}$ & $0.49 * \star \star$ & $0.34-0.70$ & 0.86 & $0.57-1.30$ & $0.77 * \star \star$ & $0.63-0.95$ & 0.99 & $0.79-1.26$ \\
\hline \multicolumn{9}{|l|}{ Residence area [Ref.: rural] } \\
\hline Urban & 0.91 & $0.70-1.18$ & 0.99 & $0.76-1.30$ & 0.92 & 0.77-1.09 & 0.96 & $0.81-1.15$ \\
\hline Metropolitan & $0.69 * \star \star$ & $0.55-0.87$ & 0.87 & $0.68-1.12$ & 0.90 & $0.78-1.04$ & 0.97 & $0.83-1.13$ \\
\hline \multicolumn{9}{|l|}{ Health-related conditions } \\
\hline Diabetes [Ref.: not diabetes] & $1.96 * \star \star$ & $1.15-3.33$ & $1.58 \#$ & $0.92-2.71$ & $2.28 * \star \star$ & $1.52-342$ & $1.49 \#$ & $0.99-2.24$ \\
\hline High blood pressure [Ref.: not high blood pressure] & $1.70 * \star \star$ & $1.05-2.74$ & $1.50 \#$ & $0.92-2.46$ & $2.42 * \star \star$ & $1.85-3.17$ & $1.93 * \star \star$ & $1.47-2.53$ \\
\hline Pseudo R2 & & - & & 0390 & & - & & 318 \\
\hline Hosmer-Lemeshow goodness of fit test ( $p$-value) & & - & 0.75 & $(0.66)$ & & - & 0.89 & $(0.54)$ \\
\hline
\end{tabular}

95\% Cl: 95\% confidence interval; OR: odds ratio; Ref.: reference.

* Crude OR obtained by simple logistic regression models, no adjustment for any covariate;

** Multiple logistic regression model adjusted for all the listed covariates;

*** Statistically significant at the 0.05 level;

\# Statistically significant at the 0.10 level. 
Table 3

Logistic regression models for the presence of clinically significant depressive symptoms in Mexican adults, by gender and educational level. 2012 Mexican National Health and Nutrition Survey (ENSANUT-2012)*.

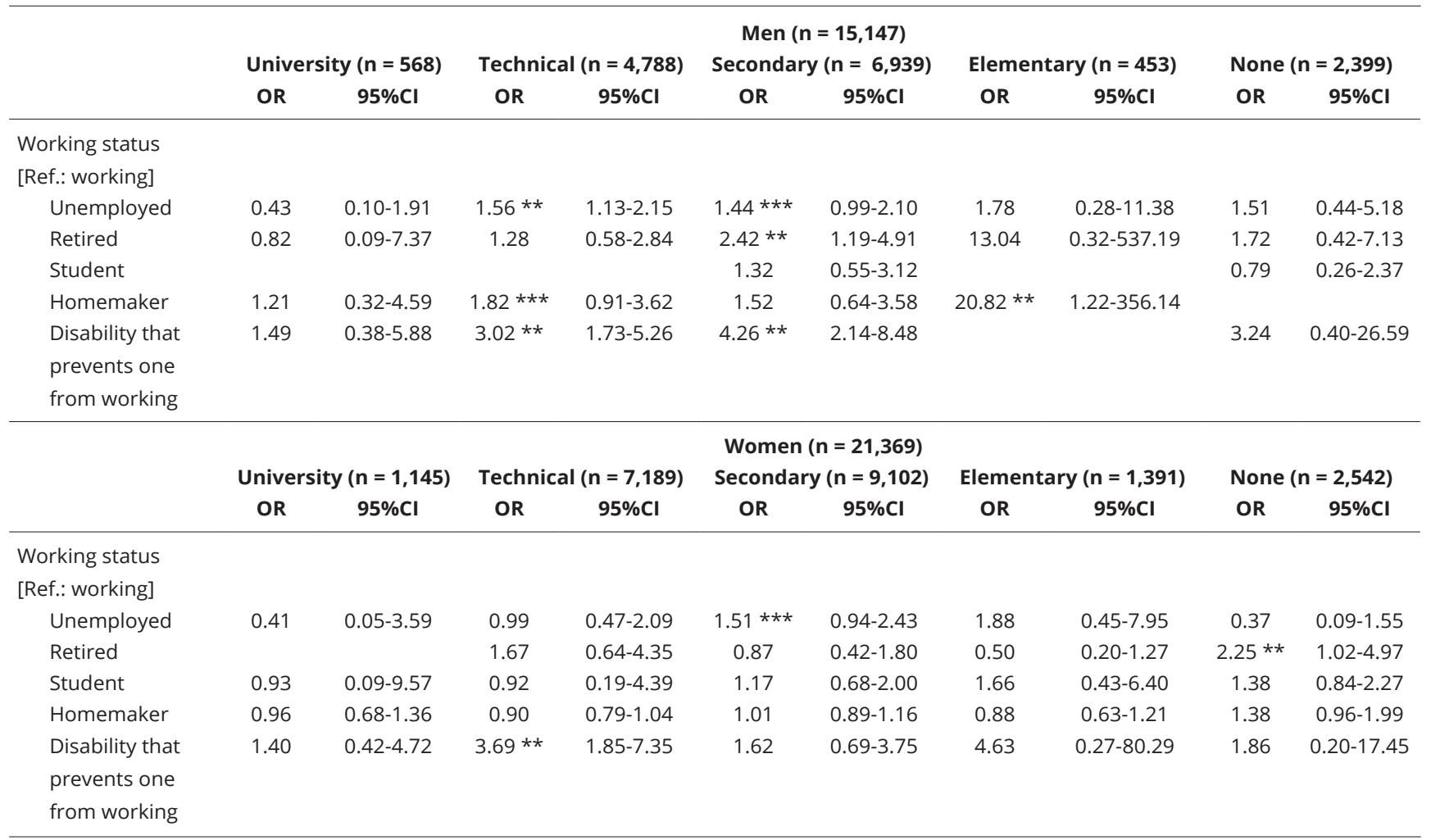

95\%Cl: 95\% confidence interval; OR: odds ratio; Ref.: reference.

Note: empty cell because of no sample in that specific category.

* All the estimates are adjusted for age, marital status, residence area, ethnicity, having health insurance, receiving money from programs, diabetes,

high blood pressure and socioeconomic status;

** Significance at the 0.05 level;

*** Significance at the 0.10 level.

In relation to the associations between employment benefits and the presence of depressive symptoms for the sub-sample of those reporting having worked over the previous week (classified as currently working), no statistically significant association was found in either men or women. All the estimates were also adjusted for age; marital status, educational level, residence area, ethnicity; health insurance status, receiving money from programs, diabetes, high blood pressure and socioeconomic status (Table 4).

\section{Discussion}

For men, association between presence of depressive symptoms and unemployment was found, even after controlling for socioeconomic status and sociodemographic and health-related variables. In the stratified analysis, this association was clearer in men with technical and secondary educational level, but it was not found in men with elementary and no formal education. This could be due to a lower statistical power given by the scarce sample in the latter strata. In the case of women, a marginal association between depression and unemployment was found in those with secondary education, as well as a positive association between depressive symptoms and being retired in women with no formal education. Also, having a disability preventing one from working was significantly associated with 
Potential associations between depressive symptoms and employment benefits on Mexican men and women who were currently working. 2012 Mexican National Health and Nutrition Survey (ENSANUT-2012)*.

\begin{tabular}{|c|c|c|c|c|c|c|}
\hline & \multicolumn{3}{|c|}{ Men $(n=11,495)$} & \multicolumn{3}{|c|}{ Women $(n=6,905)$} \\
\hline & OR & $95 \% \mathrm{Cl}$ & p-value & OR & $95 \% \mathrm{Cl}$ & p-value \\
\hline \multicolumn{7}{|l|}{ Employment income (quintlie) [Ref.: 1st) } \\
\hline 2nd & 0.94 & $0.75-1.18$ & 0.60 & 0.95 & $0.80-1.12$ & 0.55 \\
\hline 3 rd & 0.93 & $0.74-1.16$ & 0.51 & 0.99 & $0.83-1.20$ & 0.99 \\
\hline 4 th & 0.93 & $0.73-1.18$ & 0.54 & 0.80 & $0.64-1.00$ & 0.06 \\
\hline $5^{\text {th }}$ & 0.75 & $0.57-0.99$ & 0.05 & 0.89 & $0.70-1.13$ & 0.34 \\
\hline \multicolumn{7}{|l|}{ Employment benefits } \\
\hline Health care & 0.82 & $0.61-1.09$ & 0.17 & 0.85 & $0.65-1.09$ & 0.20 \\
\hline Bonuses & 1.18 & $0.84-1.64$ & 0.34 & 0.84 & $0.62-1.13$ & 0.25 \\
\hline Vacations & 0.88 & $0.60-1.28$ & 0.50 & 0.96 & $0.68-1.35$ & 0.80 \\
\hline Profit sharing & 0.88 & $0.63-1.23$ & 0.46 & 1.33 & $1.00-1.74$ & 0.06 \\
\hline Retirement savings & 0.98 & $0.69-1.38$ & 0.89 & 0.84 & $0.63-1.11$ & 0.22 \\
\hline Pseudo R2 & \multicolumn{3}{|c|}{0.0344} & \multicolumn{3}{|c|}{0.0436} \\
\hline Hosmer-Lemeshow goodness of fit test ( $p$-value) & \multicolumn{3}{|c|}{0.06} & \multicolumn{3}{|c|}{0.41} \\
\hline
\end{tabular}

* The estimates are adjusted for age, marital status, residence area, educational level, ethnicity, having insurance, receiving money from programs, diabetes, high blood pressure and socioeconomic status.

having depressive symptoms in both genders. For men and women, older age and lower educational levels were positively associated with depressive symptoms, even showing a dose-response effect in these variables (higher odds at lower levels and at higher ages).

Although the association between having a job and lower levels of psychiatric morbidity has usually been reported 30,31, this study found a differential effect on men and women. This finding requires an understanding of gender roles as sociocultural constructs that can shape how women and men differently perceive unemployment. For men, an identity crisis could explain the association between a lack of employment and depressive symptoms since performing the role of provider has traditionally been the backbone of masculinity, and the perception of not fulfilling that role could cause emotional distress 32. Participation in the labor market enables men to carry out the role assigned to them as providers for their families as well as to receive social recognition and perform functions that are typically considered to be male, such as technical skills and holding authority positions 19,32. Losing this status might be a condition that boosts the occurrence of depressive symptoms. This could also be explained through the Jahoda's latent deprivation model, which includes status and identity as one of the "latent consequences of job" 33,34. According to this model, association between not working and depressive symptoms is not only explained by the loss of the economic benefits of a paid work, but also the loss of the status and identity, time structure, shared experience with people outside the family group, collective purpose, and regular activity 33,34 .

For women, the presence of depressive symptoms does not appear to be associated with unemployment in this analysis and sample. This could be related with the fact that women's work is less socially and economically rewarded and unemployment does not jeopardize their gender identity. Although the rate of women's participation in the workforce in Mexico increased from 34.3\% in 2005 to $40.9 \%$ in 2013 35, their inclusion in the workforce has not been accompanied by a redistribution of household responsibilities to their partners. In this country, women work $20.6 \%$ more hours than men because of this additional responsibility and, thus, $65 \%$ of the work performed by women is unpaid 36. However, in the case of uneducated women, an association between depressive symptoms and being retired was found. This result could suggest a negative impact of retirement, which could be associated with the psychological affectation that would produce this vital event 37 . However, as several studies have suggested, the association between depression and retirement is highly variable 
in each context and its evidence is still very inconsistent, since this relationship will depend on the retirement conditions (voluntary or involuntary), the working conditions of the last job, and the benefits acquired in retirement, mainly if one has access to a pension 38 . Unfortunately, we do not have information about the retirement conditions to explore this relationship in our study.

Regardless of these differences, some factors involved in depressive symptoms are common for men and women, such as age and lower educational level as risk factors. This could be explained by a better ability to cognitively respond to stressful stimuli, which people learn with higher educational levels, as well as the positive impact of education that has been found on employment and work conditions 39,40 . On the other hand, likelihood of depressive symptoms was observed to increase as age increased; in fact, recent research has reported that depressive symptoms occur more often among older adults 41,42, significantly affecting their health 43 .

In Mexico, the quality of work conditions is generally poorer for women than for men. Women have less control, lower job positions, and lower pay for the same types of activities 35,36. This affects their mental health 20,44 and could explain why this study found work was not suggested as a protective factor for women in this sample. Future studies should: (1) include other socioeconomic factors as race/ethnicity that have been associated with depression in other contexts 45; (2) incorporate factors related to work conditions since these have been found to be more important to mental health than being employed or unemployed 46,47; and (3) adjust these estimates for specific health conditions such as diabetes and hypertension.

One of the limitations of this study is that the definition of depressive symptoms includes a broad range of categories, and this analysis could not distinguish among major depressive disorders, the presence of symptoms associated with short grief periods and other types of depression 48 . Another substantial limitation is that this study is a cross-sectional analysis, and the directionality of the specific relationships in the model cannot be determined. Therefore, the association between unemployment and depression could also be explained by the greater difficulty of men with depressive tendencies in finding and keeping jobs, known as "social selectivity" 49, namely, a possible bidirectional effect between depression and unemployment.

Another limitation of this study is that we measured the employment status in the last week and, unfortunately, we could not determine whether the employment was temporary or long-term. In addition, since work conditions are different for men and women, the lack of information about more specific job conditions is an important limitation of this study. Including measurements of sectors, job positions, level of work, employment quality, kind of employment (permanent or temporary), working conditions, as well as the type in terms of control and demand, effort-reward imbalance, organizational justice, job insecurity 46 , other stressful life events, among others, would be important since these factors significantly influence the workers' mental health 50 . New studies must incorporate these measures in a more detailed approach and provide an analysis of the context of the workrelated challenges that Mexico is currently facing, raising from the labor inequalities and the informal job, a weak recovery of the salaries and the need for a major participation of women in the labor market 20,24, as well as from racial and ethnic discrimination in the job market 51 . These situations that are beyond the scope of this study must be considered.

This study evidences that gender dynamics of labor must be considered to study the potentially differential effect of employment on the mental health of women and men. Female labor force participation shows a great variation among developing countries. This participation is high in the poorest countries, where women engage in subsistence activities; it declines in middle-income countries, in which the industrial sector offers more opportunities for men; and it increases as education levels improve and new job opportunities are created for women 52 . This relation between women's participation in the labor market and economic growth in developing countries makes particularly relevant the integration of a gender perspective to understand the impact of both labor participation and the quality of employment on people's mental health in these countries. In this sense, we follow the United Nations recommendations presented in the document Gender Equality, Work, and Health: A Review of the Evidence, having performed an analysis by gender with a nationally representative sample and the category "homemaker" as a type of employment 53.

In conclusion, this study draws attention to the importance of identifying the social employment conditions associated with depressive symptoms in a developing country, particularly regarding 
gender differences. The authors suggest future studies should analyze longitudinally contextual factors of employment to consider not only the participation in the job market but also the quality of employment. Scientific evidence about these issues will help governments develop public health, economic, and social policies to urge employers to improve workplace gender equality, address the relation between employment and gender roles, create more opportunities for women in the labor market, encourage men to share the domestic work, and promote healthy work environments for women and men.

\section{Contributors}

J. A. Fernández-Niño contributed in the conception and design, acquisition of data, analysis and interpretation of data, drafting the article, and critical revision of the final version. L. J. Bonilla-Tinoco participated in the analysis and interpretation of data; drafting the article and critical revision of the final version. C. I. Astudillo-García collaborated in the design, interpretation of data, drafting the article and critical revision of the final version. E. F. Manrique-Hernández participated in the conception and design, drafting the article and critical revision of the final version. V. Giraldo-Gartner contributed in the interpretation of data, drafting the article and critical revision of the final version.

\section{References}

1. Global Burden of Disease Study 2013 Collaborators. Global, regional, and national incidence, prevalence, and years lived with disability for 301 acute and chronic diseases and injuries in 188 countries, 1990-2013: a systematic analysis for the Global Burden of Disease Study 2013. Lancet 2015; 386:743-800.

2. Judd LL, Paulus MP, Wells KB, Rapaport MH. Socioeconomic burden of subsyndromal depressive symptoms and major depression in a sample of the general population. Am J Psychiatry 1996; 153:1411-7.

3. Pietrzak RH, Kinley J, Afifi TO, Enns MW, Fawcett J, Sareen J. Subsyndromal depression in the United States: prevalence, course, and risk for incident psychiatric outcomes. Psychol Med 2013; 43:1401-14.

4. Doherty JL, Owen MJ. Genomic insights into the overlap between psychiatric disorders: implications for research and clinical practice. Genome Med 2014; 6:29.

5. Nutt DJ. Relationship of neurotransmitters to the symptoms of major depressive disorder. The J Clin Psychiatry 2008; 69 Suppl E1:4-7.

6. Assareh AA, Sharpley CF, McFarlane JR, Sachdev PS. Biological determinants of depression following bereavement. Neurosci Biobehav Rev 2015; 49:171-81.

7. van Santen A, Vreeburg SA, Van der Does AJ, Spinhoven P, Zitman FG, Penninx BW. Psychological traits and the cortisol awakening response: results from the Netherlands Study of Depression and Anxiety. Psychoneuroendocrinology 2011; 36:240-8. 
8. Li JX. Pain and depression comorbidity: a preclinical perspective. Behav Brain Res 2015; 276:92-8.

9. Andreoulakis E, Hyphantis T, Kandylis D, Iacovides A. Depression in diabetes mellitus: a comprehensive review. Hippokratia 2012; 16:20514.

10. Munhoz TN, Santos IS, Matijasevich A. Major depressive episode among Brazilian adults: a cross-sectional population-based study. J Affect Disord 2013; 150:401-7.

11. Teo AR, Choi H, Valenstein M. Social relationships and depression: ten-year follow-up from a nationally representative study. PLoS One 2013; 8:e62396.

12. Nguyen TT, Tchetgen Tchetgen EJ, Kawachi I, Gilman SE, Walter S, Glymour MM. The role of literacy in the association between educational attainment and depressive symptoms. SSM Popul Health 2017; 3:586-93.

13. Lorant V, Deliege D, Eaton W, Robert A, Philippot P, Ansseau M. Socioeconomic inequalities in depression: a meta-analysis. Am J Epidemiol 2003; 157:98-112.

14. Theorell T, Hammarstrom A, Aronsson G, Traskman Bendz L, Grape T, Hogstedt C, et al. A systematic review including meta-analysis of work environment and depressive symptoms. BMC Public Health 2015; 15:738.

15. Yoo KB, Park EC, Jang SY, Kwon JA, Kim SJ, Cho $\mathrm{KH}$, et al. Association between employment status change and depression in Korean adults. BMJ Open 2016; 6:e008570.

16. Weich S, Lewis G, Jenkins SP. Income inequality and the prevalence of common mental disorders in Britain. Br J Psychiatry 2001; 178:222-7.

17. van der Noordt $M$, Jizelenberg H, Droomers $M$, Proper KI. Health effects of employment: a systematic review of prospective studies. Occup Environ Med 2014; 71:730-6.

18. Modini M, Joyce S, Mykletun A, Christensen H, Bryant RA, Mitchell PB, et al. The mental health benefits of employment: results of a systematic meta-review. Australas Psychiatry 2016;24:331-6.

19. Viveros M. La masculinidad como objeto de investigación y preocupación social. In: Viveros $\mathrm{M}$, editor. De quebradores y cumplidores: sobre los hombres, masculinidades y relaciones de género en Colombia. Bogotá: Universidad Nacional de Colombia; 2002. p. 33-118.

20. Instituto Nacional de las Mujeres. El impacto de los estereotipos y los roles de género en México. http://investigacion.cephcis.unam. $\mathrm{mx} /$ generoyrsociales/index.php/el-impactode-los-estereotipos-y-los-roles-de-generoen-mexico-instituto-nacional-de-las-mujeresinms/ (accessed on 24/Jul/2016).
21. Acosta-Rodríguez F, Rivera-Martínez M, Pulido-Rull MA. Depresión y ansiedad en una muestra de individuos mexicanos desempleados. Journal of Behavior, Health \& Social Issues 2011; 3:35-42.

22. Berenzon-Gorn S, Tiburcio-Sainz M, MedinaMora-Icaza M. Variables demográficas asociadas con la depresión: diferencias entre hombres y mujeres que habitan en zonas urbanas de bajos ingresos. Salud Ment 2005; 28:33-40.

23. Ramos-Lira L. ¿Por qué hablar de género y salud mental? Salud Ment 2014; 37:275-81.

24. Ramos G. Presentación de las perspectivas para el empleo de la OCDE 2016 y del reporte igualdad de género en la Alianza del Pacífico: promoviendo el empoderamiento económico de las mujeres. https://www.oecd.org/centro demexico/medios/discurso-gabriela-ramospanorama-del-empleo-2016.htm (accessed on 06/Jul/2017).

25. Instituto Nacional de Estadística y Geografía. Indicadores de ocupación y empleo: cifras oportunas durante febrero de 2017. Aguascalientes: Instituto Nacional de Estadística y Geografía; 2017.

26. Romero-Martínez M, Shamah-Levy T, FrancoNúñez A, Villalpando S, Cuevas-Nasu L, Gutiérrez JP, et al. Encuesta Nacional de Salud y Nutrición 2012: diseño y cobertura. Salud Pública Méx 2013; 55 Suppl 2:S332-40.

27. Gracia E, Herrero J. Una medida breve de la sintomatología depresiva (CESD-7). Salud Ment 2007; 30:40-6.

28. Salinas-Rodríguez A, Manrique-Espinoza B, Acosta-Castillo I, Téllez-Rojo MM, FrancoNúñez A, Gutiérrez-Robledo LM, et al. Validación de un punto de corte para la Escala de Depresión del Centro de Estudios Epidemiológicos, versión abreviada (CESD-7). Salud Pública Méx 2013; 55:267-74.

29. Booysen F, van der Berg S, Burger R, Maltitz $\mathrm{MV}$, Rand GD. Using an asset index to assess trends in poverty in seven Sub-Saharan African countries. World Dev 2008; 36:1113-30.

30. Jefferis BJ, Nazareth I, Marston L, MorenoKustner B, Bellon JA, Svab I, et al. Associations between unemployment and major depressive disorder: evidence from an international, prospective study (the predict cohort). Soc Sci Med 2011; 73:1627-34.

31. Paul KI, Moser K. Unemployment impairs mental health: meta-analyses. J Vocat Behav 2009; 74:264-82.

32. Oliffe JL, Rasmussen B, Bottorff JL, Kelly MT, Galdas PM, Phinney A, et al. Masculinities, work, and retirement among older men who experience depression. Qual Health Res 2013; 23:1626-37. 
33. Jahoda M. Work, employment, and unemployment: values, theories, and approaches in social research. Am Psychol 1981; 36:184-91.

34. Jahoda M. Economic recession and mental health: some conceptual issues. J Soc Issues 1988; 44:13-23.

35. Instituto Nacional de Estadística y Geografía. Cuenta satélite del trabajo no remunerado de los hogares de México 2013. Preliminar, año base 2008. Aguascalientes: Instituto Nacional de Estadística y Geografía; 2014.

36. Instituto Nacional de Estadística y Geografía. Estadísticas a propósito del día internacional de la mujer (8 de marzo). Datos económicos nacionales. Aguascalientes: Instituto Nacional de Estadística y Geografía; 2016.

37. Szinovacz ME, Davey A. Retirement transitions and spouse disability: effects on depressive symptoms. J Gerontol B Psychol Sci Soc Sci 2004; 59:S333-42.

38. Leinonen T, Lahelma E, Martikainen P. Trajectories of antidepressant medication before and after retirement: the contribution of socio-demographic factors. Eur J Epidemiol 2013; 28:417-26.

39. Márquez Jiménez A. La relación entre educación superior y mercado de trabajo en México. Una breve contextualización. Perfiles Educativos 2011; XXXIII:169-85.

40. Sinha Mukherjee S. More educated and more equal? A comparative analysis of female education and employment in Japan, China and India. Gend Educ 2015; 27:846-70.

41. Fernández-Niño JA, Manrique-Espinoza BS, Bojorquez-Chapela I, Salinas-Rodríguez A. Income inequality, socioeconomic deprivation and depressive symptoms among older adults in Mexico. PLoS One 2014; 9:e108127.

42. Fiske A, Wetherell JL, Gatz M. Depression in older adults. Annu Rev Clin Psychol 2009; 5:363-89.

43. Bustos-Vázquez E, Fernández-Niño JA, Astudillo-García CI. Autopercepción de la salud, presencia de comorbilidades y depresión en adultos mayores mexicanos: propuesta y validación de un marco conceptual simple. Biomédica (Bogotá) 2017; 37 Suppl 1:92-103.

44. Plaisier I, de Bruijn JG, Smit JH, de Graaf R, Ten Have M, Beekman AT, et al. Work and family roles and the association with depressive and anxiety disorders: differences between men and women. J Affect Disord 2008; 105:63-72.

45. Hudson DL, Puterman E, Bibbins-Domingo K, Matthews KA, Adler NE. Race, life course socioeconomic position, racial discrimination, depressive symptoms and self-rated health. Soc Sci Med 2013; 97:7-14.
46. Kim TJ, von dem Knesebeck O. Is an insecure job better for health than having no job at all? A systematic review of studies investigating the health-related risks of both job insecurity and unemployment. BMC Public Health 2015; 15:985.

47. Butterworth P, Leach LS, Strazdins L, Olesen SC, Rodgers B, Broom DH. The psychosocial quality of work determines whether employment has benefits for mental health: results from a longitudinal national household panel survey. Occup Environ Med 2011; 68:806-12.

48. Rodríguez MR, Nuevo R, Chatterji S, Ayuso-Mateos JL. Definitions and factors associated with subthreshold depressive conditions: a systematic review. BMC Psychiatry 2012; 12:181.

49. Mastekaasa A. Unemployment and health: selection effects. J Community Appl Soc Psychol 1996; 6:189-205.

50. Sanderson K, Andrews G. Common mental disorders in the workforce: recent findings from descriptive and social epidemiology. Can J Psychiatry 2006; 51:63-75.

51. Ortiz L, Ayala CI, Pérez-Salgado D. Posición socioeconómica, discriminación y color de piel en México. Perfiles Latinoamericanos 2018; 26:215-39.

52. Gaddis I, Klasen S. Economic development, structural change, and women's labor force participation: a reexamination of the feminization U hypothesis. J Popul Econ 2014; 27:63981.

53. World Health Organization. Gender equality, work and health: a review of the evidence. Geneva: World Health Organization; 2006. 


\section{Resumen}

El objetivo de este estudio fue estimar la relación entre el estatus de empleo y los sintomas depresivos entre adultos mexicanos, así como estudiar su efecto diferencial por género. Se realizó un estudio transversal con 36.516 adultos entre 20 y 59 años de edad, procedentes de la Encuesta Nacional de Salud y Nutrición de 2012. Los síntomas depresivos se evaluaron usando la Center for Epidemiological Studies Depression Scale (CES-D), y el estatus de empleo se determinó una semana antes de la encuesta. Los modelos de regresión logística fueron estratificados por género, nivel educativo y ajustados por condiciones sociodemográficas, además de condiciones de salud informadas para estimar la asociación entre los sintomas depresivos y el estatus de empleo. La prevalencia de los sintomas clinicamente depresivos fue 7,59\% para los hombres $y$ 18,62\% para las mujeres. En el caso de los hombres, quienes estaban desempleados tuvieron más predisposición de presentar síntomas depresivos $(O R=1,66$; IC95\%: 1,08-2,55), respecto a quienes estaban trabajando. Para las mujeres, el estatus de empleo no está asociado a la presencia de sintomas depresivos, excepto en estudiantes $(O R=$ 1,57; IC95\%: 1,02-2,43), si lo comparamos con quienes estaban trabajando. En ambos géneros, la baja laboral estuvo asociada con sintomas depresivos. El estar empleado supuso tener niveles más bajos de morbilidad psiquiátrica, aunque el efecto estimado es diferente para hombres y mujeres. Las politicas de salud ocupacional deberían considerar estas condiciones.

Empleo; Desempleo; Identidad de Género; Depresión; Salud Mental

\section{Resumo}

O estudo teve como objetivo estimar a relação entre situação laboral e sintomas depressivos em adultos mexicanos, além de explorar o efeito de acordo com gênero. Foi realizado um estudo transversal em uma amostra de 36.516 adultos com idade entre 20 e 59 anos, usando dados da Pesquisa Nacional de Saúde e Nutrição, de 2012. Os sintomas depressivos foram avaliados com a Center for Epidemiological Studies Depression Scale (CES-D), e a situação laboral foi determinada uma semana antes da pesquisa. Modelos de regressão logística foram estratificados por gênero e nivel de escolaridade e ajustados por condições sociodemográficas e de saúde para estimar a associação entre sintomas depressivos e situação laboral. A prevalência de sintomas depressivos foi de 7,59\% em homens e 18,62\% em mulheres. Os homens desempregados mostraram maior probabilidade de apresentar sintomas depressivos, quando comparados aos que estavam trabalhando (OR = 1,66; IC95\%: 1,08-2,55). Para as mulheres, a situação laboral não mostrou associação com a presença de sintomas depressivos, exceto entre as estudantes $(O R=1,57$; IC95\%: 1,02-2,43), comparadas às que estavam trabalhando. Em ambos os sexos, a incapacidade para o trabalho esteve associada a sintomas depressivos. Embora o fato de estar empregado esteja associado a níveis menores de morbidade psiquiátrica, o efeito estimado é diferente para homens e mulheres. As politicas de saúde ocupacional devem levar em conta essas condições.

Emprego; Desemprego; Identidade de Gênero; Depressão; Saúde Mental
Submitted on 20/Dec/2017

Final version resubmitted on 12/Apr/2018

Approved on 03/May/2018 